\title{
KOMPOSISI HASIL TANGKAPAN LOBSTER (Panulirus spp) YANG DIDARATKAN DI PANGKALAN PENDARATAN IKAN KARANGDUWUR KABUPATEN KEBUMEN JAWA TENGAH
}

\author{
Catch Composition of Lobsters (Panulirus spp) at Karangduwur Landing Site in Kebumen Regency, \\ Central Java \\ Oleh:

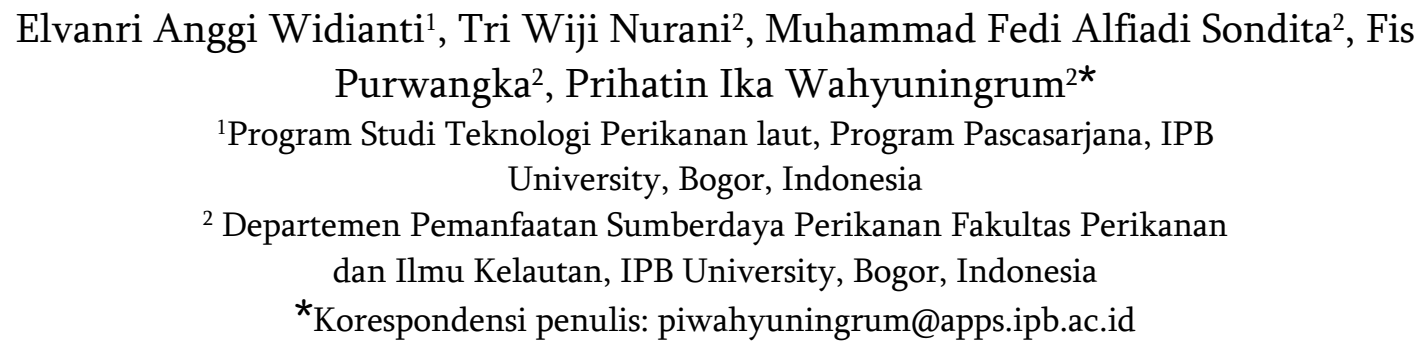

\begin{abstract}
ABSTRAK
Perairan Pantai Kebumen memiliki kekayaan sumberdaya perikanan yang tinggi pada jenis ikan-ikan pelagis dan jenis krustasea, terutama lobster. Terdapat enam jenis lobster yang berada di Perairan Pantai Ayah Kabupaten Kebumen yaitu lobster pasir ( $P$. homarus), lobster batu $(P$. penicillatus), lobster batik ( $P$. longipes), lobster mutiara ( $P$. ornatus), lobster bambu $(P$. versicolor $)$ dan lobster pakistan ( $P$. polyphagus). Tujuan penelitian adalah mendeskripsikan unit penangkapan lobster dan mengidentifikasi komposisi hasil tangkapan lobster di Perairan Pantai Ayah Kabupaten Kebumen. Pengambilan data dilakukan di PPI Karangduwur, Kecamatan Ayah, Kabupaten Kebumen pada bulan November 2020-Januari 2021. Hasil penelitian menunjukkan bahwa alat penangkapan lobster yang digunakan oleh nelayan yaitu jaring insang dan bubu. Nelayan setempat masih menggunakan kapal berukuran <5 GT untuk melakukan operasi penangkapan lobster secara one day fishing. Hasil tangkapan terbanyak yaitu jenis lobster pasir ( $P$. homarus) sebesar 5657 ekor dan paling sedikit diperoleh lobster jenis pakistan ( $P$. polyphagus) sebanyak 7 ekor. Berdasarkan distribusi jenis lobster di Perairan Pantai Ayah Kabupaten Kebumen dapat disimpulkan bahwa 75\% lobster sudah layak tangkap. Penetapan ukuran layak tangkap tersebut sesuai dengan Peraturan Menteri Kelautan dan Perikanan Nomor 17 tahun 2021.
\end{abstract}

Kata kunci: komposisi hasil tangkapan, lobster, Panulirus spp, perairan Kebumen

\begin{abstract}
Kebumen coastal area has potential for pelagic fish and crustaceans, especially lobsters. There are six types of lobster found in Ayah waters, Kebumen Regency, namely P. homarus, P. penicillatus, P. longipes, P. ornatus, P. versicolor, and P. polyphagus. This study aimed to describe the lobster fishing unit and identify the composition of lobster catches in the coastal waters of Ayah Beach, Kebumen Regency. Data collected at Karangduwur Landing site, Ayah District, Kebumen Regency, from November 2020 to January 2021. The results showed that the fishing gear used by fishermen were gillnet and trap. In addition, local fishers used vessels up to 5 GT to catch lobster. The catch dominated by P. homarus 5657 and the least was $\mathrm{P}$. polyphagus. Based on the distribution of lobster species it could be concluded that 75\% of lobster were suitable for catching. The determination of the catchablesize follows Ministry of Marine Affair and Fisheries Number 17 year 2021 Regulation.
\end{abstract}

Key words: catch composition, Kebumen waters, lobster, Panulirus spp 


\section{PENDAHULUAN}

Perairan Pantai Kebumen salah satu daerah pesisir di Selatan Jawa Tengah yang memiliki beberapa pangkalan pendaratan ikan, diantaranya PPI Karangduwur, PPI Argopeni, PPI Pasir. PPI Karangduwur adalah pangkalan pendaratan ikan yang terletak di Kecamatan Ayah, Kabupaten Kebumen dengan hasil produksi perikanan tertinggi apabila dibandingkan dengan PPI lainnya. Produksi perikanan di PPI Karangduwur identik dengan ikan-ikan pelagis dan jenis krustasea, terutama lobster. Hal ini dikarenakan kondisi di perairan pantai Ayah sesuai dengan karakteristik habitat yang disukai oleh lobster yaitu perairan berkarang dan bergelombang dengan arus yang tinggi (Kusuma et al. 2012). Berdasarkan data Dinas Kelautan dan Perikanan Kabupaten Kebumen (2018) produksi lobster terbesar mencapai 11,47 ton di daerah Karangduwur, Kecamatan Ayah. Pemanfataan lobster sebagian besar masih mengandalkan alat tangkap yang sederhana seperti jaring insang (gillnet).

Beberapa macam lobster yang terdapat di perairan Ayah yaitu lobster pasir (Panulirus homarus), lobster batu (Panulirus penicillatus), lobster batik (Panulirus longipes), lobster mutiara (Panulirus ornatus), lobster bambu (Panulirus versicolor) dan lobster pakistan (Panulirus polyphagus) (Kadafi et al. 2006; Saputra 2009). Tingginya nilai jual setiap jenis lobster, sehingga nelayan melakukan penangkapan dengan intensitas yang tinggi (Saputra 2009). Tindakan ini dikhawatirkan mempengaruhi kondisi sumberdaya lobster di perairan tersebut. Sampai saat ini, informasi awal terkait dengan data hasil tangkapan dan ukuran panjang lobster yang terkangkap di Perairan Kebumen masih terbatas. Oleh karena itu, diperlukan penelitian tentang ukuran panjang dan berat lobster yang tertangkap di perairan pantai Ayah dalam rangka pengelolaan perikanan lobster yang berkelanjutan (Irfannur et al. 2018).

Lebih lanjut, pemerintah telah mengeluarkan Peraturan Menteri Kelautan dan Perikanan Republik Indonesia no. 17 tahun 2021 tentang pengelolaan lobster (Panulirus spp), kepiting (Scylla spp), dan rajungan (Portunus spp) di wilayah Negara Republik Indonesia. Peraturan tersebut mengatur penangkapan lobster ketika kondisi bertelur serta pembatasan panjang karapas lobster diatas $6 \mathrm{~cm}$ atau berat 150 gram per ekor untuk jenis lobster pasir dan diatas $8 \mathrm{~cm}$ atau berat diatas 200 gram per ekor untuk lobster jenis lainnya. Dikeluarkannya aturan tersebut, menjadi pedoman untuk proses penangkapan lobster di wilayah Republik Indonesia, termasuk di perairan Pantai Ayah. Sehingga pemerintah daerah perlu mendapatkan data tentang ukuran dan panjang lobster tersebut dikaitkan dengan regulasi yang sudah ditetapkan sebagai data dasar untuk pengelolaan perikanan lobster.

Penelitian bertujuan untuk mendeskripsikan unit penangkapan lobster dan mengidentifikasi jenis, panjang dan berat hasil tangkapan lobster di Perairan Pantai Ayah Kabupaten Kebumen. Penelitian ini diharapkan mampu menjadi acuan untuk menghadapi berbagai permasalahan yang terjadi terkait pemanfaatan lobster seperti: terbatasnya informasi terkait kondisi biologi lobster, karakteristik hasil penangkapan dan usaha tentang perikanan lobster di Perairan Pantai Ayah Kabupaten Kebumen.

\section{METODE PENELITIAN}

Penelitian dilakukan di PPI Karangduwur, Kecamatan Ayah, Kabupaten Kebumen. Lokasi penelitian terlihat pada Gambar 1. Pengambilan data telah dilaksanakan pada bulan November 2020Januari 2021. 


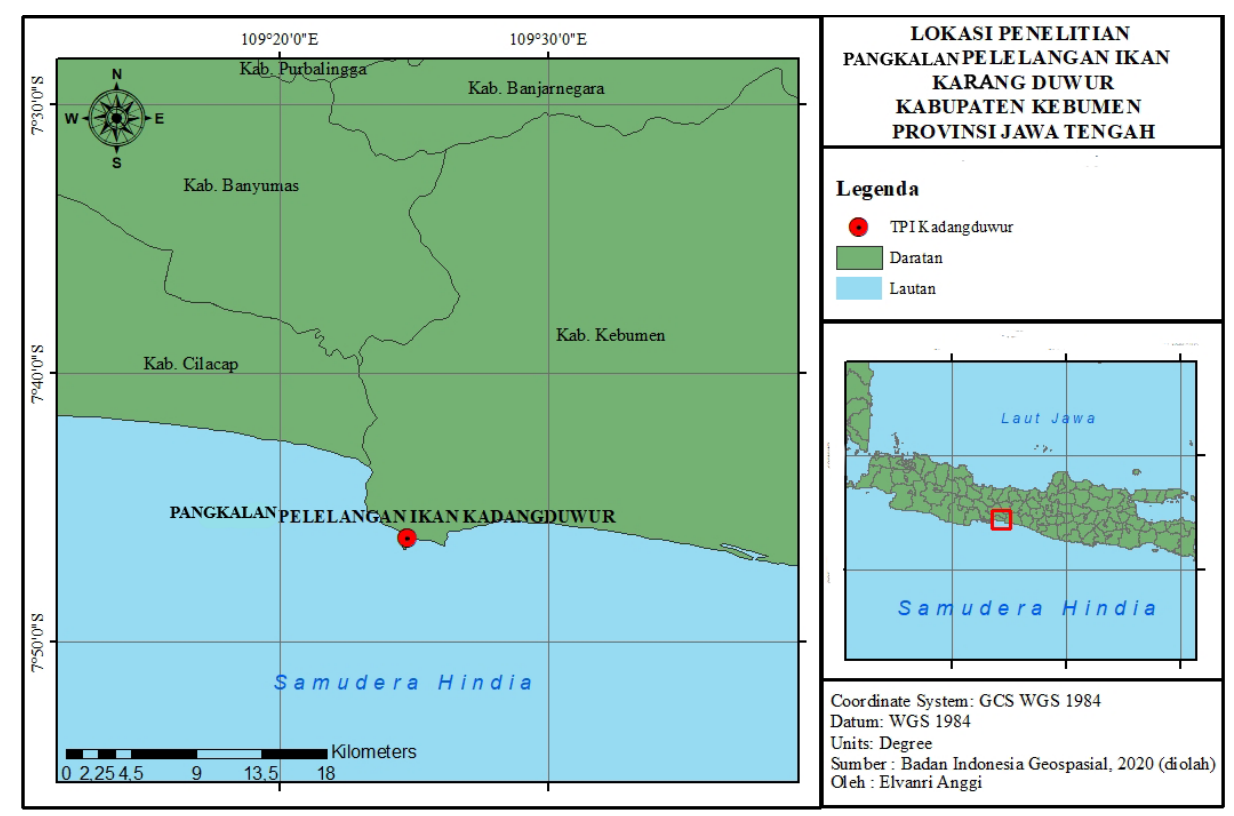

Gambar 1 Peta tempat penelitian di perairan Pantai Ayah

Data yang diambil untuk menjawab tujuan pertama meliputi: dimensi utama kapal (lebar, panjang dan dalam kapal), jenis dan ukuran alat tangkap, metode operasi penangkapan lobster dan lokasi penangkapan lobster. Data tersebut diperoleh dengan melakukan wawancara kepada nelayan (pemilik atau nakhkoda) dari 20 unit penangkapan yang ada di TPI Karangduwur. Jumlah 20 responden tersebut dianggap representatif untuk mewakili populasi karena mencapai $10 \%$ dari populasi (Santoso et al. 2016). Kegiatan wawancara dilakukan selama 20 hari dengan melakukan wawancara pada setiap satu pemilik kapal yang ditemui (accidental sampling) dengan beberapa kriteria yaitu:

1. Nelayan mampu berkomunikasi dengan baik.

2. Nelayan yang telah melakukan pendaratan kapal di TPI Karangduwur.

3. Nelayan bersedia untuk melakukan wawancara.

4. Nelayan yang memiliki tujuan utama melakukan penangkapan lobster.

5. Nelayan yang sebagian besar hasil tangkapannya adalah lobster.

Pengambilan data lobster dilaksanakan dengan metode accidental sampling, teknik pengambilan sampel lobster dengan cara mengukur panjang karapas, berat, jenis kelamin lobster yang ditemui oleh peneliti dengan dibantu enumerator. Ketentuan lobster yang dijadikan sampel yaitu telah didaratkan oleh nelayan dan ditimbang oleh petugas di Tempat Pelelangan Ikan Karangduwur. Pengukuran tersebut dilakukan 5 hari dalam satu minggu selama bulan November 2020-Januari 2021. Cara pengukuran panjang karapas yaitu dengan cara mengukur panjang dari tepi post orbital hingga ujung post terior karapas lobster (Sparre dan Venema 2001). Lobster yang telah diukur selama penelitian diperoleh sebanyak 6.883 ekor lobster dengan jumlah betina sebesar 4.807 ekor dan jantan 2.076 ekor.

Analisis data yang digunakan untuk mendeskripsikan unit penangkapan lobster yaitu analisis deskriptif kualitatif. Selanjutnya terkait data komposisi hasil tangkapan lobster dianalisis dengan menggunakan deskriptif-tabulatif. Komposisi hasil tangkapan lobster direpresentasikan melalui grafik hasil tangkapan untuk seluruh hasil tangkapan jenis lobster di perairan pantai Ayah. Data terkait panjang karapas dan berat lobster direpresentasikan melalui bentuk tabel dan grafik ukuran setiap jenis lobster yang diperoleh. Analisis terkait panjang karapas yang diperoleh juga dikaitkan dengan PERMEN-KP No 17 tahun 2021 bagian ke tiga pada pasal 7 terkait penangkapan dan atau pengeluaran lobster (Panulirus spp). 


\section{HASIL DAN PEMBAHASAN}

\section{Hasil \\ Unit Penangkapan Lobster}

Operasi penangkapan lobster yang dilakukan oleh nelayan perairan Pantai Ayah, Kabupaten Kebumen menggunakan berbagai macam alat tangkap, diantaranya jaring lobster atau yang sering disebut oleh nelayan setempat dengan nama jaring sirang dan bubu (Gambar 2). Alat tangkap yang lebih banyak digunakan oleh nelayan setempat adalah jaring sirang. Pemilihan alat tangkap yang dominan digunakan oleh nelayan sama seperti yang dilakukan dengan nelayan di daerah Gunung Kidul yaitu, lebih menyukai jaring sirang dibandingkan alat tangkap lainnya (Suman et al. 2019). Jaring sirang yang digunakan oleh nelayan setempat rata-rata dengan ukuran mata jaring sebesar 5-5,5 inch. Bahan jaring lobster yang digunakan terbuat dari polyamide monofilament. Serta dengan diameter sekitar 0,25-0,35 mm. Metode penangkapan lobster yang dilakukan nelayan yaitu dengan sistem one day fishing dengan cara menaburkan jaring pada sore hari dan merendamnya selama semalam. Pengambilan hasil tangkapan dilakukan pada pagi hari berikutnya. Lama perendaman dipengaruhi oleh kondisi perairan. Apabila perairan memiliki ombak yang besar maka perendaman akan dilakukan selama dua hari atau lebih menunggu hingga ombak kembali tenang (Damora et al. 2018).

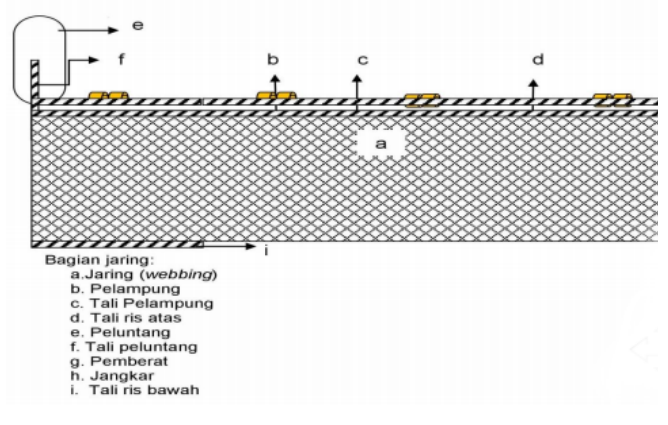

(a)

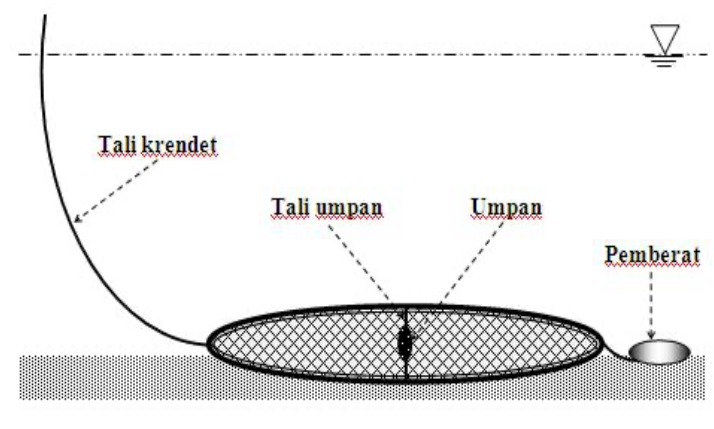

(b)

Sumber: Dokumentasi studi literatur

Gambar 2 (a) Jaring lobster (sirang/gillnet) dan (b) Bubu sebagai alat tangkap penangkapan lobster

Jumlah kapal yang terdapat di perairan Ayah sekitar 200 kapal. Armada kapal yang digunakan untuk melakukan penangkapan lobster yaitu kapal yang berbahan dasar fiber mayoritas berukuran $<5$ GT dengan ukuran panjang kapal sebesar 9,5 m, lebar yaitu 1,1 m, dan dalam sebesar 0,75 m. Kapal dilengkapi dengan mesin tempel yang dipasang di luar dan biasanya letaknya di belakang kapal. Kapal yang digunakan rata-rata sudah milik pribadi dan umunya satu kapal berisi 2-3 orang yang terdiri antara pemilik kapal dan ABK kapal.

Berdasarkan hasil wawancara yang telah dilakukan, mayoritas nelayan memanfaatkan sektor perikanan sebagai mata pencaharian utama karena kondisi geografis yang berdekatan dengan pantai. Tingkat pendidikan nelayan setempat kebanyakan hanya lulusan jenjang Sekolah Dasar (SD) dan Sekolah Menengah Pertama (SMP). Nelayan setempat belum memiliki surat sertifikasi khusus terkait pelatihan dalam melakukan operasi penangkapan ikan. Mereka hanya mengandalkan pengalaman turun-temurun dan belajar sendiri. Nelayan setempat juga masih berpegang pada tradisi-tradisi baik yang masih dilestarikan dengan tujuan untuk melestarikan sumberdaya laut. Tradisi tersebut ditunjukkan dengan kepercayaan nelayan setempat yang tidak melakukan operasi penangkapan ikan pada hari tertentu setiap bulannya. Nelayan setempat percaya bahwa mereka tidak melakukan penangkapan pada hari tertentu sebagai salah satu bentuk usaha untuk memulihkan sumberdaya yang telah dieksploitasi. 
Daerah operasi penangkapan lobster tersebar hampir di sepanjang perairan pantai Ayah Kabupaten Kebumen. Daerah penangkapan lobster terletak di perairan yang berkarang dan memiliki gelombang arus yang tinggi. Musim penangkapan lobster berdasarkan hasil wawancara dengan nelayan dan analisis data hasil produksi TPI Karangduwur tahun 2016-2020 menunjukkan bahwa penangkapan lobster di Kabupaten Kebumen dapat dilakukan setiap bulan khususnya pada bulan Oktober-Januari. Puncak musim penangkapan lobster terjadi pada bulan November.

\section{Komposisi Hasil Tangkapan Lobster}

\section{Identifikasi Jenis dan Habitat Lobster}

Jenis lobster yang tertangkap dan ditemukan di Perairan Ayah Kabupaten Kebumen terdiri dari 6 jenis lobster yaitu terdapat lobster pasir (Panulirus homarus) sebanyak 5.657 ekor dengan presentase sebesar 82\%; lobster mutiara (Panulirus ornatus) sebanyak 866 ekor dengan presentase jumlah 13\%; lobster batu (Panulirus penicillatus) sebanyak 178 ekor dengan presentase jumlah sebesar 3\%; lobster bambu (Panulirus versicolor) sebanyak 68 ekor dengan jumlah presentase sebesar 1\%. Lobster batik (Panulirus longipes) sebanyak 107 ekor dengan jumlah presentase sebanyak 1\%, dan yang terakhir yaitu lobster pakistan (Panulirus polyphagus) sebanyak 6 ekor (Tabel 1). Hal ini sesuai dengan pernyataan (Kadafi et al. 2006).

Tabel 1 Komposisi hasil tangkapan lobster

\begin{tabular}{lccccc}
\hline \multirow{2}{*}{ Jenis Lobster } & \multicolumn{2}{c}{ Jantan } & \multicolumn{2}{c}{ Betina } & N total \\
\cline { 2 - 5 } & $\mathrm{N}$ (ekor) & $\%$ & $\mathrm{~N}$ (ekor) & $\%$ & (ekor) \\
\hline Panulirus polyphagus (Lobster Pakistan) & 1 & $0 \%$ & 6 & $0 \%$ & 7 \\
Panulirus homarus (Lobster Pasir) & 1635 & $79 \%$ & 4022 & $84 \%$ & 5657 \\
Panulirus longipes (Lobster Batik) & 45 & $2 \%$ & 62 & $1 \%$ & 108 \\
Panulirus ornatus (Lobster Mutiara) & 329 & $16 \%$ & 537 & $11 \%$ & 866 \\
Panulirus penicillatus (Lobster Batu) & 48 & $2 \%$ & 130 & $3 \%$ & 178 \\
Panulirus versicolor (Lobster Bambu) & 18 & $1 \%$ & 50 & $1 \%$ & 68 \\
\hline \multicolumn{1}{c}{ Total } & 2076 & $100 \%$ & 4807 & $100 \%$ & 6883 \\
\hline
\end{tabular}

Setiap jenis lobster memiliki ciri-ciri fisik dan habitat hidup yang berbeda. Lobster pasir (Panulirus homarus) adalah salah satu jenis lobster yang memiliki ciri-ciri warna dasar yang kehijaun hingga kecoklatan dengan bintik-bintik putih pada abdomen. Sering ditemui pada habitat daerah karang berpasir dengan kedalaman sekitar 1-5 m. Selain itu, lobster pasir (Panulirus homarus) juga dapat ditemukan pada kedalaman hingga $90 \mathrm{~m}$ (Kadafi et al. 2006). Lobster mutiara (Panulirus ornatus) adalah salah satu lobster yang memiliki harga jual yang tinggi dibanding lobster lainnya. Lobster ini memiliki corak warna berupa hijau-kebiruan dibagian karapas. ditemukan pada perairan tenang dekat dengan terumbu karang atau batu berkarang dengan kedalaman sekitar 1-10 m, namun masih dapat ditemukan hingga kedalaman perairan yang mencapai $200 \mathrm{~m}$ (Kadafi et al. 2006). Lobster ini memiliki kebiasaan hidup soliter atau berpasangan serta adanya musim migrasi pada bulan tertentu (Carpenter dan Niem 1998). Lobster batu (Panulirus penicillatus) memiliki ciri-ciri warna biru kehitam-hitaman dengan bintik-bintik yang tidak begitu jelas pada setiap ruas abdomen. Lobster ini sering ditemukan oleh nelayan pada habitat perairan yang dangkal dengan kedalaman sekitar 1-4 m dengan kedalaman maksimum sebesar $16 \mathrm{~m}$ (Kadafi et al. 2006). Lobster batik (Panulirus longipes) merupakan lobster yang memiliki warna tubuh coklat gelap, bercak-bercak putih yang dihubungkan dengan garis berwarna jingga. Lobster batik (Panulirus longipes) memiliki habitat pada daerah dengan kondisi perairan yang berkarang dengan perairan yang jernih dan arus yang rendah serta pada kedalaman hingga $130 \mathrm{~m}$ (Kadafi et al. 2006). Lobster bambu (Panulirus versicolor) adalah salah satu jenis lobster yang berwarna kehijauan. Ciri-ciri lainnya yaitu pada warna abdomennya yang berwarna kehijauan dan memiliki garis putih yang diapit garis biru pada setiap segmen ruas abdomen. Habitatnya pada kedalaman perairan kurang dari $16 \mathrm{~m}$. Lobster pakistan (Panulirus polyphagus) merupakan lobster jenis lobster yang 
cenderung menyukai daerah dasar laut berlumpur dan terkadang juga ditemukan pada dasar perairan batu berpasir. Lobster ini memiliki warna dasar hijau dengan garis berwarna putih kekuningan pada setiap segmen abdomen.

\section{Panjang Karapas Lobster}

Ukuran panjang karapas lobster pasir (Panulirus homarus) yang diperoleh selama penelitian berkisar antara 70-79 $\mathrm{mm}$ dengan rata-rata tertangkap pada panjang karapas 74,50 $\pm 2,25 \mathrm{~mm}$. Kisaran panjang karapas lobster mutiara (Panulirus ornatus) antara 90-99 mm dengan panjang karapas rata-rata sebesar 92,26 \pm 0,63 mm. Panjang karapas lobster bambu (Panulirus versicolor) antara 60-69 $\mathrm{mm}$ dengan panjang rata-rata 76,30 $\pm 13,00 \mathrm{~mm}$. Panjang karapas untuk lobster batu (Panulirus penicilatus) berkisar antara 70-79 $\mathrm{mm}$ dengan panjang karapas rata-rata 80,61 \pm 8,40 $\mathrm{mm}$. Kemudian untuk lobster batik (Panulirus longipes) dan lobster pakistan (Panulirus polyphagus) secara berurutan memiliki panjang karapas antara 80-89 $\mathrm{mm}$ dan 60-79 mm masing-masing memiliki panjang karapas rata-rata sebesar 81,16 0,74 mm dan 95,00 $\pm 14,28 \mathrm{~mm}$ (Gambar 3) dan (Tabel 2). Lobster pasir adalah lobster yang banyak ditemukan di perairan pantai Ayah Kabupaten Kebumen. Sedangkan lobster yang paling sedikit ditemukan yaitu lobster pakistan.
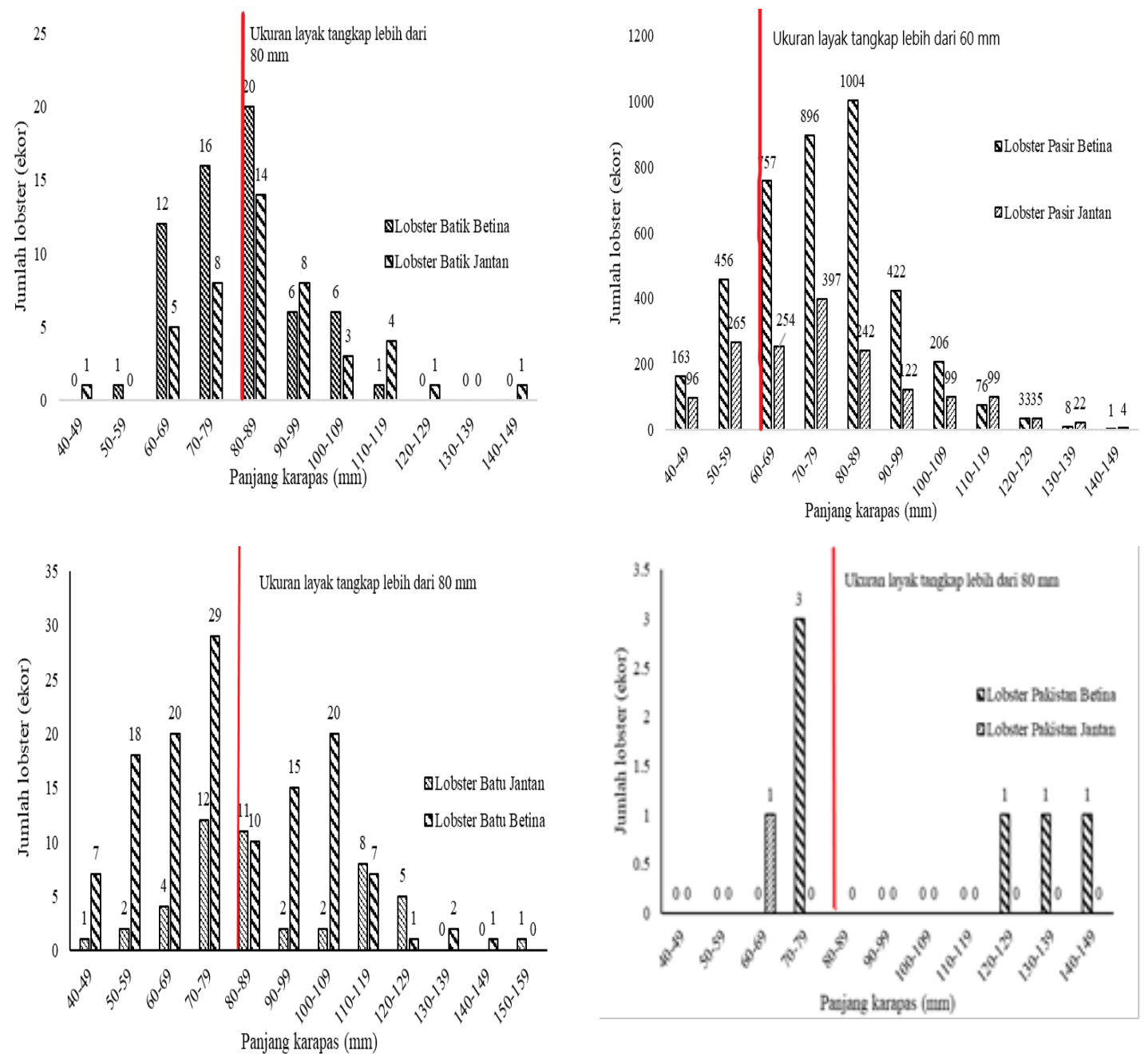

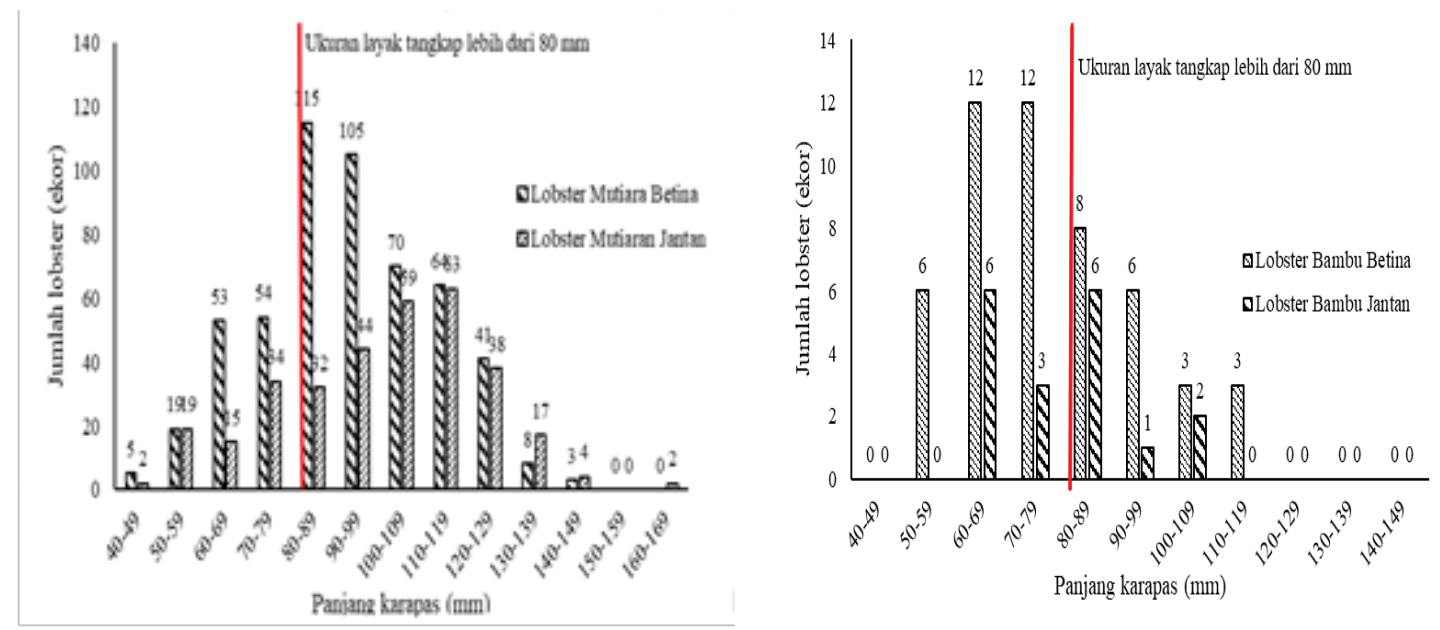

Gambar 3 Distribusi ukuran panjang karapas 6 jenis lobster

Tabel 2 Ukuran panjang karapas lobster yang tertangkap

\begin{tabular}{lccccc}
\hline \multicolumn{1}{c}{ Jenis Lobster } & $\begin{array}{c}\text { Minimum } \\
(\mathrm{mm})\end{array}$ & $\begin{array}{c}\text { Maksimum } \\
(\mathrm{mm})\end{array}$ & $\begin{array}{c}\text { Rata-rata } \\
(\mathrm{mm})\end{array}$ & $\begin{array}{c}\text { Modus } \\
(\mathrm{mm})\end{array}$ & $\begin{array}{c}\text { Jumlah } \\
\text { sampel } \\
(\mathrm{ekor})\end{array}$ \\
\hline $\begin{array}{l}\text { Lobster Pasir } \\
\text { (Panulirus homarus })\end{array}$ & 40 & 140 & $74,50 \pm 2,25$ & $70-79$ & 5657 \\
$\begin{array}{l}\text { Lobster Mutiara } \\
\text { (Panulirus ornatus })\end{array}$ & 40 & 160 & $92,26 \pm 0,63$ & $90-99$ & 866 \\
$\begin{array}{l}\text { Lobster Bambu } \\
\text { Panulirus versicolor })\end{array}$ & 50 & 110 & $76,30 \pm 13,00$ & $60-69$ & 68 \\
$\begin{array}{l}\text { Lobster Batu } \\
\text { Panulirus penicilatus })\end{array}$ & 40 & 150 & $80,61 \pm 8,40$ & $70-79$ & 178 \\
$\begin{array}{l}\text { Lobster Batik } \\
\text { (Panulirus longipes) }\end{array}$ & 40 & 140 & $81,16 \pm 0,74$ & $80-89$ & 107 \\
$\begin{array}{l}\text { Lobster Pakistan } \\
\text { (Panulirus polyphagus })\end{array}$ & 60 & 140 & $95,00 \pm 14,28$ & $60-79$ & 7 \\
\hline
\end{tabular}

\section{Berat Lobster}

Setiap jenis lobster di perairan Pantai Ayah, Kabupaten Kebumen memiliki distribusi berat yang berbeda-beda (Gambar 4 dan Tabel 3). Lobster pasir (Panulirus homarus) yang tertangkap memiliki berat berkisar antara 183-239 gram dengan jumlah rata-rata pada kisaran 221 $\pm 73,67$ gram. Berat lobster mutiara (Panulirus ornatus) berkisar antara 164-298 gram tangkapan terbanyak rata-rata skitar 305,80 $\pm 164,42$ gram. Berat lobster bambu (Panulirus versicolor) berkisar antara 98-133 gram dengan ratarata ukuran berat sekitar 193,70 $\pm 55,51$ gram. Berat lobster batu (Panulirus penicilatus) berkisar antara 170-289 gram dengan ukuran rata-rata sebesar 257,90 $\pm 112,82$ gram. Selanjutnya untuk lobster batik (Panulirus longipes) dan lobster pakistan (Panulirus polyphagus) memiliki berat secara berurutan

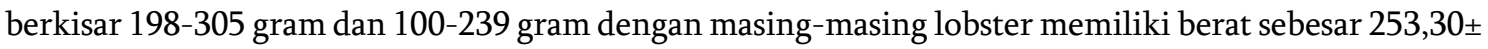
91,70 gram dan $355,70 \pm 144,28$ gram. Lobster mutiara merupakan lobster yang memiliki berat rata-rata terbesar dan lobster bambu merupakan lobster yang memiliki rata-rata ukuran berat yang kecil. 

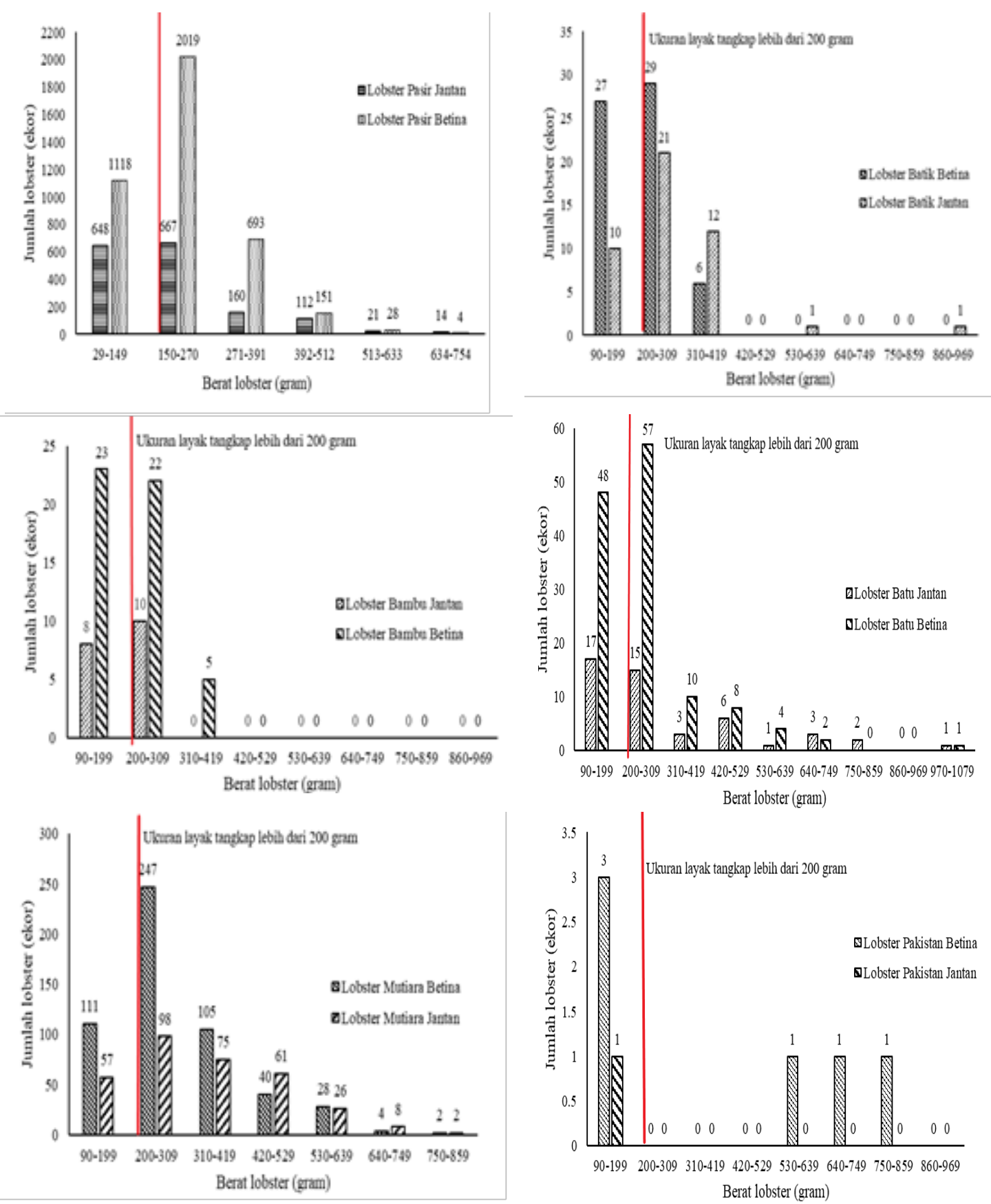

Gambar 4 Distribusi ukuran berat 6 jenis lobster

Tabel 3 Distribusi berat lobster yang tertangkap

\begin{tabular}{lccccc}
\hline \multicolumn{1}{c}{ Jenis Lobster } & $\begin{array}{c}\text { Minimum } \\
\text { (gr) }\end{array}$ & $\begin{array}{c}\text { Maksimum } \\
\text { (gr) }\end{array}$ & $\begin{array}{c}\text { Rata-rata } \\
\text { (gr) }\end{array}$ & $\begin{array}{c}\text { Modus } \\
\text { (gr) }\end{array}$ & $\begin{array}{c}\text { Jumlah } \\
\text { sampel } \\
\text { (ekor) }\end{array}$ \\
\hline $\begin{array}{l}\text { Lobster Pasir } \\
\text { Panulirus homarus) }\end{array}$ & 29 & 1100 & $221 \pm 73,67$ & $183-259$ & 5657 \\
$\begin{array}{l}\text { Lobster Mutiara } \\
\text { Panulirus ornatus) }\end{array}$ & 29 & 1500 & $305,80 \pm 164,42$ & $164-298$ & 866 \\
$\begin{array}{l}\text { Lobster Bambu } \\
\text { (Panulirus versicolor) }\end{array}$ & 98 & 350 & $193,70 \pm 55,51$ & $98-133$ & 68
\end{tabular}




\begin{tabular}{lccccc}
\hline \multicolumn{1}{c}{ Jenis Lobster } & $\begin{array}{c}\text { Minimum } \\
(\mathrm{gr})\end{array}$ & $\begin{array}{c}\text { Maksimum } \\
(\mathrm{gr})\end{array}$ & $\begin{array}{c}\text { Rata-rata } \\
(\mathrm{gr})\end{array}$ & $\begin{array}{c}\text { Modus } \\
\text { (gr) }\end{array}$ & $\begin{array}{c}\text { Jumlah } \\
\text { sampel } \\
(\mathrm{ekor})\end{array}$ \\
\hline $\begin{array}{l}\text { Lobster Batu } \\
\text { (Panulirus penicilatus) }\end{array}$ & 50 & 1000 & $257,90 \pm 112,82$ & $170-289$ & 178 \\
$\begin{array}{l}\text { Lobster Batik } \\
\text { (Panulirus longipes) }\end{array}$ & 90 & 950 & $253,30 \pm 91,70$ & $198-305$ & 107 \\
$\begin{array}{l}\text { Lobster Pakistan } \\
\text { Panulirus polyphagus) }\end{array}$ & 100 & 800 & $355,70 \pm 144,28$ & $100-239$ & 7 \\
\hline
\end{tabular}

\section{PEMBAHASAN}

Alat penangkapan lobster yaitu jaring sirang (gillnet) dan bubu. Namun diantara kedua alat tangkap tersebut jaring sirang lebih dominan digunakan. Hal ini dikarenakan jaring sirang dianggap sebagai alat tangkap yang paling mudah untuk dioperasikan (tidak membutuhkan keahlian khusus). Selain itu, biaya operasional penggunaan jaring sirang lebih murah dibandingkan dengan alat tangkap lainnya, karena tidak memerlukan biaya pembelian umpan terlebih dahulu didalam operasi penangkapan. Jumlah jaring sirang yang dioperasikan atau dibawa oleh nelayan dalam satu kali melaut yaitu sekitar 30-60 kinting (pis). Sedangkan, untuk alat tangkap bubu hanya digunakan oleh sebagian kecil nelayan yang di dalam setiap operasional penangkapan lobster hanya membawa sekitar 20-30 pis. Jaring sirang di daerah pantai Ayah yang berukuran antara 5-5,5 inch. Apabila dibandingkan dengan ukuran berdasarkan daerah penangkapan lainnya seperti Aceh memiliki ukuran 4-4,5 inch (Kembaren dan Nurdin 2015), Gunung kidul berukuran 5 inch (Suman et al. 2019), jaring sirang di perairan pantai Ayah memiliki ukuran mesh size yang cukup lebar. Nelayan setempat termasuk nelayan tradisional yang masih mengandalkan turun-temurun dalam melakukan operasi penangkapannya. Penggunaan alat bantu GPS baru digunakan oleh beberapa nelayan dalam operasi penangkapan lobster.

Daerah perairan yang cenderung berbatuan dan berkarang di sepanjang pantai memudahkan nelayan dalam memperoleh hasil tangkapan lobster. Hampir disepanjang perairan pantai Ayah dapat dengan mudah ditemukan lobster. Hal ini sesuai dengan pernyataan Kusuma et al. (2012) yang menyatakan bahwa habitat yang disukai oleh lobster yaitu perairan berkarang dan bergelombang dengan arus yang tinggi. Musim penangkapan lobster terjadi pada bulan Oktober-Januari. Menurut nelayan pada saat itu merupakan awal terjadinya musim hujan yang diyakini hasil tangkapan lobster akan meningkat pada saat tersebut. Menurut Damora et al. (2018), fenomena awal musim hujan merupakan salah satu upaya untuk meningkatkan hasil tangkapan lobster. Hal ini dikarenakan pada musim penghujan mengakibatkan peningkatan aktivitas lobster di sekitar terumbu karang karena terjadi penurunan suhu perairan sekitar kondisi ini sangat sesuai dengan habitat lobster (Sunarto et al. 2016). Kadar salinitas air laut yang turun dan adanya air hujan yang mengakibatkan kekeruhan permukaan air laut sehingga lobster akan keluar dari sarangnya.

Lobster yang paling banyak jumlahnya di Perairan Pantai Ayah yaitu lobster pasir (Panulirus homarus) sebanyak 5657 ekor dan lobster yang paling sedikit yaitu lobster pakistan (Panulirus polyphagus) sebanyak 7 ekor. Hal ini disebabkan setiap lobster memiliki perbedaan habitat sehingga berpengaruh terhadap jumlah hasil tangkapan nelayan. Menurut Damora et al. (2018) perbedaan lokasi dapat mempengaruhi pola pertumbuhan lobster walaupun memiliki jenis lobster yang sama. Selain itu, adanya perbedaan dari faktor ekologi dan biologi juga dapat mempengaruhi pertumbuhan lobster. Faktor ekologi yang dimaksud meliputi suhu, salinitas, klorofil-a dan pH. Faktor biologi tersebut, antara lain jenis kelamin, perkembangan gonad, fase pertumbuhan dan kebiasaan makan (Froese 2006). Berdasarkan identifikasi jenis lobster yang terbanyak diperoleh bahwa Perairan Kabupaten Kebumen memiliki karakteristik yang cocok dengan habitat lobster pasir. Perairan yang terjal dan terdapat banyak terumbu karang menjadi habitat utama lobster pasir (Linting dan Widodo 2017). Selain itu, kebiasaan lobster pasir dan lobster batu salah satunya suka bergerombol dan sering berada di pesisir pantai juga menjadi salah satu faktor mudahnya nelayan didalam melakukan penangkapan lobster 
dalam jumlah banyak. Sedangkan untuk lobster mutiara, batik, bambu dan pakistan memiliki sifat yang soliter sehingga cukup susah untuk diperoleh dalam jumlah yang banyak (Moosa dan Aswandy 1984).

Lobster adalah salah satu hewan golongan krustasea dengan waktu yang cukup lama untuk melakukan reproduksi. Hal ini dikarenakan lobster memiliki nilai laju pertumbuhan yang kurang dari 1 berarti memiliki pertumbuhan yang lambat (Sparre dan Venema 2001). Oleh karena itu, untuk mencegah terjadinya tindakan tangkap berlebih oleh nelayan lobster pemerintah menetapkan Peraturan Menteri Kelautan dan Perikanan Nomor 17 tahun 2021 tentang pengelolaan lobster (Panulirus spp), kepiting (Scylla spp), dan rajungan (Portunus spp) di wilayah Negara Republik Indonesia menyatakan lobster yang ditangkap tidak boleh dalam kondisi bertelur diluar abdomen, untuk jenis lobster pasir dengan ukuran panjang karapas diatas $6 \mathrm{~cm}$ dengan berat di atas 150 gram. Sedangkan untuk jenis lobster lainnya diperbolehkan ditangkapn dengan ukuran lebih dari $8 \mathrm{~cm}$ dengan berat diatas 200 gram. Adanya hal ini diharapkan dapat mencegah terjadinya tindakan penangkapan lobster yang tidak memperhatikan ukuran (semena-mena) sehingga mengakibatkan overfishing yang berdampak pada tidak berlanjutnya usaha perikanan lobster di daerah tersebut.

Distribusi ukuran lobster di perairan pantai Ayah untuk setiap jenisnya memiliki distribusi ukuran yang berbeda-beda. Distribusi panjang karapas lobster yaitu berkisar antara 40-160 mm. Berdasarkan distribusi 5 jenis lobster di perairan Pantai Ayah Kabupaten Kebumen dapat disimpulkan bahwa 5 jenis lobster yang tertangkap yaitu lobster batik (Panulirus longipes), lobster mutiara (Panulirus ornatus), lobster batu (Panulirus penicillatus), lobster bambu (Panulirus versicolor) dan lobster pakistan (Panulirus polyphagus) secara keseluruhan sebesar 75\% lobster rata-rata sudah layak untuk ditangkap. Selanjutnya, terkait jenis lobster pasir (Panulirus homarus) yang tertangkap di perairan pantai Ayah sebesar 82,67\% sudah layak tangkap. Hal tersebut diperoleh berdasarkan banyaknya jumlah hasil tangkapan yang layak tangkap sebanyak 4677 ekor dari jumlah keseluruhannya yaitu sebanyak 5657 ekor lobster. Penetapan ukuran layak tangkap tersebut sesuai dengan Peraturan Menteri Kelautan dan Perikanan Nomor 17 tahun 2021 yang menyatakan untuk jenis lobster pasir dengan ukuran panjang karapas diatas $6 \mathrm{~cm}$ atau $60 \mathrm{~mm}$ dengan berat diatas 150 gram dapat dikatakan sudah layak untuk ditangkap. Selain itu, apabila dibandingkan dengan lobster di daerah Yogyakarta, lobster pasir (Panulirus homarus) di perairan Pantai Ayah memiliki ukuran yang lebih besar. Hal ini dikarenakan lobster di Yogyakarta memiliki ukuran rata-rata panjang karapas yang tertangkap berkisar 31,0-96,6 mm (Damora et al. 2018). Perbedaan ukuran ini dipengaruhi adanya perbedaan kondisi lingkungan perairan dan tekanan upaya penangkapan yang terjadi pada suatu perairan.

Berat lobster yang diperoleh rata-rata sudah layak tangkap karena sudah memenuhi ukuran berat lobster yang layak tangkap yang tercantum pada Peraturan Menteri Kelautan dan Perikanan Nomor 17 tahun 2021 tentang pengelolaan lobster (Panulirus spp), kepiting (Scylla spp), dan rajungan (Portunus spp) di wilayah Negara Republik Indonesia menyatakan bahwa lobster yang layak ditangkap memiliki ukuran berat lebih dari 150 gram untuk jenis lobster pasir ( $P$. homarus) dan lebih dari 200 gram untuk jenis lainnya. Rata-rata ukuran lobster yang ditemui di perairan pantai Ayah, Kabupaten Kebumen secara keseluruhan sebesar 219,4 $\pm 72,50$ gram. Selain itu, walaupun ukuran panjang karapas lobster pendek belum tentu memiliki berat yang kecil atau sebaliknya. Hal tersebut menandakan bahwa ukuran pertumbuhan berat lobster mengalami percepatan pertumbuhan lebih dahulu dari panjang karapas lobster (Pranata et al. 2017). Lobster pasir (P. homarus) cenderung dominan banyak tertangkap dan sudah layak tangkap. Hal ini dikarenakan sifat lobster pasir $(P$. homarus) yang suka bergerombol sehingga, memudahkan nelayan dalam melakukan penangkapan dengan menggunakan jaring sirang (gillnet). Berdasarkan hasil analisis terkait komposisi hasil tangkapan lobster yang terdiri dari ukuran panjang karapas dan bobot enam jenis lobster di perairan pantai Ayah yang rata-rata hasil tangkapan terbanyak diperoleh dengan menggunakan jaring sirang (gillnet), dapat disimpulkan masih tergolong dalam kegiatan penangkapan yang lestari dan terjaga. 


\section{KESIMPULAN DAN SARAN}

Kegiatan operasi penangkapan lobster di Perairan Pantai Ayah Kabupaten Kebumen menggunakan alat tangkap jaring lobster (jaring sirang), krendet dan jaring pocong. Kapal yang digunakan berukuran <5 GT. Operasi penangkapan lobster dilakukan dengan cara one day fishing dengan puncak musim penangkapan lobster pada bulan November. Hasil tangkapan lobster di perairan pantai Ayah Kabupaten Kebumen selama bulan November 2020-Januari 2021 terdiri dari 6 jenis lobster yaitu lobster mutiara (Panulirus ornatus), lobster pasir (Panulirus homarus), lobster batu (Panulirus penicillatus), lobster bambu (Panulirus versicolor), lobster batik (Panulirus longipes) dan lobster pakistan (Panulirus polyphagus). Hasil tangkapan paling banyak diperoleh pada jenis lobster pasir (Panulirus homarus) sebesar 5657 ekor dan paling sedikit lobster jenis pakistan (Panulirus polyphagus) berbesar 7 ekor. Berdasarkan PERMEN KP NO 17 tahun 2021 lobster di perairan pantai Ayah sebesar $75 \%$ sudah layak tangkap.

Saran perlu mempertahankan kebiasaan-kebiasaan baik nelayan (taat terhadap peraturan pemerintah maupun adat, tidak menggunakan alat tangkap yang (destructive) yang mendukung terwujudnya pengelolaan sumberdaya perikanan lobster yang berkelanjutan. Perlu dilakukan kajian lebih mendalam terkait komposisi hasil tangkapan lobster dengan menggunakan jaring sirang (gillnet) pada ukuran mesh size yang tidak sama untuk mengukur tingkat selektivitas dan variasi hasil tangkapan lobster yang diperoleh oleh nelayan.

\section{UCAPAN TERIMA KASIH}

Peneliti mengucapkan terimakasih kepada instansi PPI Karangduwur, Kecamatan Ayah, Kabupaten Kebumen yang telah mengizinkan membantu proses penelitian. Ucapan terimakasih juga peneliti sampaikan kepada pihak-pihak terkait atas kerjasama saat proses pengambilan data di lokasi penelitian.

\section{DAFTAR PUSTAKA}

Bakhtiar NM, Solichin A, Saputra SW. 2013. Pertumbuhan dan laju mortalitas lobster batu hijau (Panulirus homarus) Di Perairan Cilacap Jawa Tengah. Diponegoro Journal of Maquares. 2(1):110.

Carpenter KE, Niem VH. 1998. FAO species identification guide for fishery purposes. The living marine resources of the Western Central Pacific.2(1): 160-175.

Damora A, Wardiatno Y, Adrianto L. 2018. Hasil tangkapan per upaya dan parameter populasi lobster pasir (Panulirus homarus) di Perairan Gunung Kidul. Jurnal Marine Fisheries Technology Management. 9(1): 11-24.

Direktorat Jenderal Perikanan, 1992. Udang Barong. Buletin Warta Mina. No.63. Jakarta:19.

Direktorat Jenderal Perikanan. 1989. Krendet Alat Tangkap Lobster. Buletin Warta Mina. No.32. Jakarta: 30.

Ernawati, Kembaren DD, Suprapto, Suprapto, Sumiono, Bambang TK. 2014. Parameter populasi lobster bambu (Panulirus versicolor) di Perairan Utara Kabupaten Sikka dan sekitarnya. BAWAL. 7(3): 121-128.

Froese R. 2006. Cube law condition factor and weight-length relationships: History meta-analysis and recommendations. Journal Apply Ichthyolgy. 10(11): 1439-0426. 
Froese R, Binohlan C. 2000. Empirical relationships to estimate asymptotic length, length at first maturity and length at maximum yield per recruit in fishes, with a simple method to evaluate length frequency data. Journal Fisheries Biology. 10: 1006-1194.

Irfannur, Wahju RI, Riyanto M. 2018. Komposisi Hasil Tangkapan Dan Ukuran Lobster Dengan Jaring Insang Di Perairan Kabupaten Aceh Jaya. Albacore Jurnal Penelitian Perikanan Laut. 1(2):211223.

Kadafi M, Widaningroem R, Soeparno S. 2006. Aspek biologi dan potensi lestari sumberdaya lobster (Panulirus spp.) di Perairan Pantai Kecamatan Ayah Kabupaten Kebumen. Jurnal Perikanan Universitas Gadjah Mada. 8(1): 108-117.

Kembaren DD, Lestari P, Ramadhani R. 2015. Parameter biologi lobster pasir (Panulirus homarus) di Perairan Tabanan, Bali. BAWAL Perikanan Tangkap. 7(1):35-42.

Kembaren DD, Nurdin E. 2015. Distribusi ukuran dan parameter populasi lobster pasir (Panulirus homarus) di Perairan Aceh Barat. BAWAL. 7.(3): 121-128.

Khikmawati LT, Boesono H, Sardiyatno. 2015. The effect of differences of immersing and wall slope of traps lobster (Panulirus sp.) in Argopeni Water Kebumen. Journal of Fisheries Resource Utilization Management and Technology. 4(2): 83-92.

Kusuma RD, Asriyanto, Sardiyatmo. 2012. Pengaruh kedalaman dan umpan berbeda terhadap hasil tangkapan lobster (Panulirus sp) dengan jaring lobster (bottom gill net monofilament) di Perairan Argopeni Kabupaten Kebumen. Journal of Fisheries Resource Utilization Management and Technology. 1(1): 11-21.

Linting ML, Widodo AA. 2017. Status perikanan jaring tramel dan kontribusinya terhadap perikanan tangkap di Perairan Pantai Selatan Kebumen. Jurnal Penelitian Perikanan Indonesia. 8(1):69 73.

Pauly D. 1984. Fish population dynamics in tropical waters: A manual for use with programmable calculators. International Center for Living Aquatic Resources Management.

[PERMEN] Peraturan Menteri Kelautan dan Perikanan 17 Tahun 2021 tentang Pengelolaan Lobster (Panulirus spp.), Kepiting (Scylla spp.), dan Rajungan (Portunus spp.) di Wilayah Negara Republik Indonesia. 2021.

Pranata B, Sabariah V, Suhaemi S. 2017. Aspek biologi dan pemetaan daerah penangkapan lobster (Panulirus spp) di Perairan Kampung Akudiomi Distrik Yaur Kabupaten Nabire. Jurnal Sumberdaya Akuatik Indopasifik. 1(1):1-14.

Sparre P, Venema SC. 2001. Introduction to tropical fish stock assessment. Pt. 1: Manual.- Pt. 2. (306):12.

Sugiyono. 2016. Metode Penelitian Kuantitatif Kualitatif dan RnD. Bandung(ID): CV Alfabeta.

Suman A, Hasanah A, Pane ARP, Panggabean AS. 2019. Penangkapan, parameter populasi serta tingkat pemanfaatan lobster pasir (Panulirus homarus) dan lobster batu (Panulirus penicillatus) di Perairan Gunung Kidul dan sekitarnya. Jurnal Penelitian Perikanan Indonesia. 25(3):147-160.

Sunarto, Sulistiono, Setyobudiandi I. 2015. Hubungan jenis kepiting bakau (Scylla Spp.) dengan mangrove dan substrat di tambak Silvofishery Eretan, Indramayu. Marine Fisheries. 6(1): 59-68.

Tim Perikanan WWF-Indonesia. 2015. Perikanan Lobster Laut.:1-3. 